\title{
E- Mail Communication Applications in Patient Physician Communication: A SYSTEMATIZED REVIEW
}

\author{
Mahnaz Samadbeik ${ }^{1}$, Fatemeh Kalhori' ${ }^{1}$, Abaas Harati², Ali Garavand ${ }^{*}{ }^{*}$ \\ ${ }^{1}$ Department of Health Information Technology, School of Paramedicine, Lorestan University of Medical Sciences, Khorramabad, Iran \\ 2 Department of Health Information Management and Technology, School of Paramedicine, Shahid Beheshti University of Medical Sciences, \\ Tehran, Iran.
}

\begin{tabular}{ll}
\hline Article Info & A B S T R A C T \\
\hline $\begin{array}{l}\text { Article type: } \\
\text { Review }\end{array}$ & Introduction: \\
\hline $\begin{array}{l}\text { Article History: } \\
\text { Received: } 2019-01-31\end{array}$ & Email is a beneficial way in order to increase interaction between patients \\
Revised: $2019-02-25$ & physicians are able to increase patients' health level and the amount of \\
Accepted: $2019-03-06$ & physicians' duties. This study was done to identify the applications of email
\end{tabular}

* Corresponding author:

Ali Garavand

Department of Health Information

Management and Technology,

School of Paramedicine, Shahid

Beheshti University of Medical

Sciences, Tehran, Iran.

E-mail:virya67@yahoo.com

\section{Material and Methods:}

The current study is a systematized review conducted in 2019. The literature search done by the relevant keywords to the subject in databases: Web of Science, Scopus, PubMed, Science Direct and Cochran. After applying inclusion and exclusion criteria 34 articles were included. Based on the study's aim, results were summarized and reported by Content Analysis Technique.

\section{Results:}

The results showed that 15 articles (44\%) using email technology to investigate laboratory's resources. Utilizing email in 9 articles $(26 \%)$ showed that it caused an improvement in healthcare quality.

\section{Conclusion:}

Results showed that use of email's capabilities has a key role in improving healthcare quality as well as time saving. So, we suggest that the authorities deploy certain and codified mechanism in order to utilizing email communication between patients and physicians.

Keywords:

Communication, email communication, patient and physician communication

How to cite this paper

Samadbeik M, Kalhori F, Harati A, Garavand A. E-mail Communication Applications in Patient Physician Communication: A Systematized Review. Front Health Inform. 2019; 8(1): e7. DOI: 10.30699/fhi.v8i1.175

\section{INTRODUCTION}

The utility of information technology is necessary to improve services, increasing knowledge, the quality of information, more effective communications, more completed results and more applications of information [1]. With regard to evolution of communication tools, nowadays using of telecommunication networks such as internet is widespread [2]. Internet has made a setting of novel communication ways in order to use it for both suppliers and consumers of healthcare services [ $\underline{3}]$ that could be a complimentary to or substitute for face to face traditional communications or even telephone contact [4]. The evolution of communications has made an effect on healthcare system; it's used for the prevention [ $\underline{5}, \underline{6}]$, diagnosis and treatment of diseases [ $[\underline{5}, 7]$ and finally patients' health development $[\underline{5}, \underline{6}]$. However the inappropriate use of internet threatens people health conditions in interchanging of patients' health information []․ According to the previous studies, it's possible to communicate via mobile $[\underline{3}, \underline{8}, \underline{9}]$, text message []ㅡ, telephone contact [10], Facebook, website [1ㅣ] and email $[\underline{3}, \underline{5}, \underline{8}, \underline{10}-\underline{15}]$. Email is alike to a letter and was already used to unimportant conversations and twosome dialogues [12]. Email is a new technology in healthcare employed in wide spectrum of diseases over the last decade. In fact it ties up environmental around through internet or computer [16] and is one of the most important 
practices to improve relations amongst people []]. The internet can support the relationship between physician and patient [ $[$ ] . This is a kind of bilateral agreed relation between physician and patient that is based on trust, physicians' moral commitment and supporting patients' welfare [17]. A proper relation between them is the cornerstone of the high quality healthcare [4]. Telemedicine services lead to an easy access to physicians for patients and shaping up new relational methods between them [16]. Numerous studies have mentioned various applications of email in communications area between physician and patients such as improvement in relation between patients and healthcare providers [18-20], increasing interaction between physicians and patients $[\underline{12}, \underline{17}$, $\underline{18}, 21]$, exchanging individual's message at home with medical organizations [21] , easy to use [22] and encouraging healthcare providers to do their responsibilities $[\underline{8}, \underline{21}]$, saving of health providers' time in order to finding patients and providing a round-the-clock connection with them if necessary $[\underline{18}, \underline{20}, \underline{22}, \underline{23}]$, improving interaction with patient [23], maintaining continuity of relation between patient and physician, protection of patient, the continuance in healthcare and its improvement $[\underline{18}$, 22-24], enhancing patient safety and reducing human errors [25]. Although using this communication tool is easy, it is susceptible of some problems such as individual privacy violation [26], security problems $[\underline{3}, \underline{27}]$, written errors, misunderstanding of patients emotions and losing the advantage of visiting in person such as sympathy. With regard to the importance of email communication between physician and patient some studies were done in the current decade [28 $\underline{26}$ ], for example: Houston et al. concluded that before implementation of email communications between physicians and patients, it is necessary to specify its effect on them, patients management, relation between physician and patient, results of patients health and patients education because its effective in patients satisfaction level and reducing risk [28]. In another study Atherton et al. conducted a literature review of email communication between physicians and patients in healthcare [29]. However, our surveys showed that no systematized literature review of email communication applications between physician and patient has conducted in the last five years, also in recent years a few studies were done about Patient Physician e mail Communications therefore the aim of this study was to identify email communication applications between physicians and patients.

\section{MATERIAL AND METHODS}

With the aim of identifying email communication applications between physician and patient, the current study was conducted in 2016. The study began with a search of selected databases include PubMed, Web of Sciences, Cochran, Science Direct,
Google scholar by a combination of keywords by imposing a limitation on English language and title Table 1.

Table1: The Search Strategy of the Research

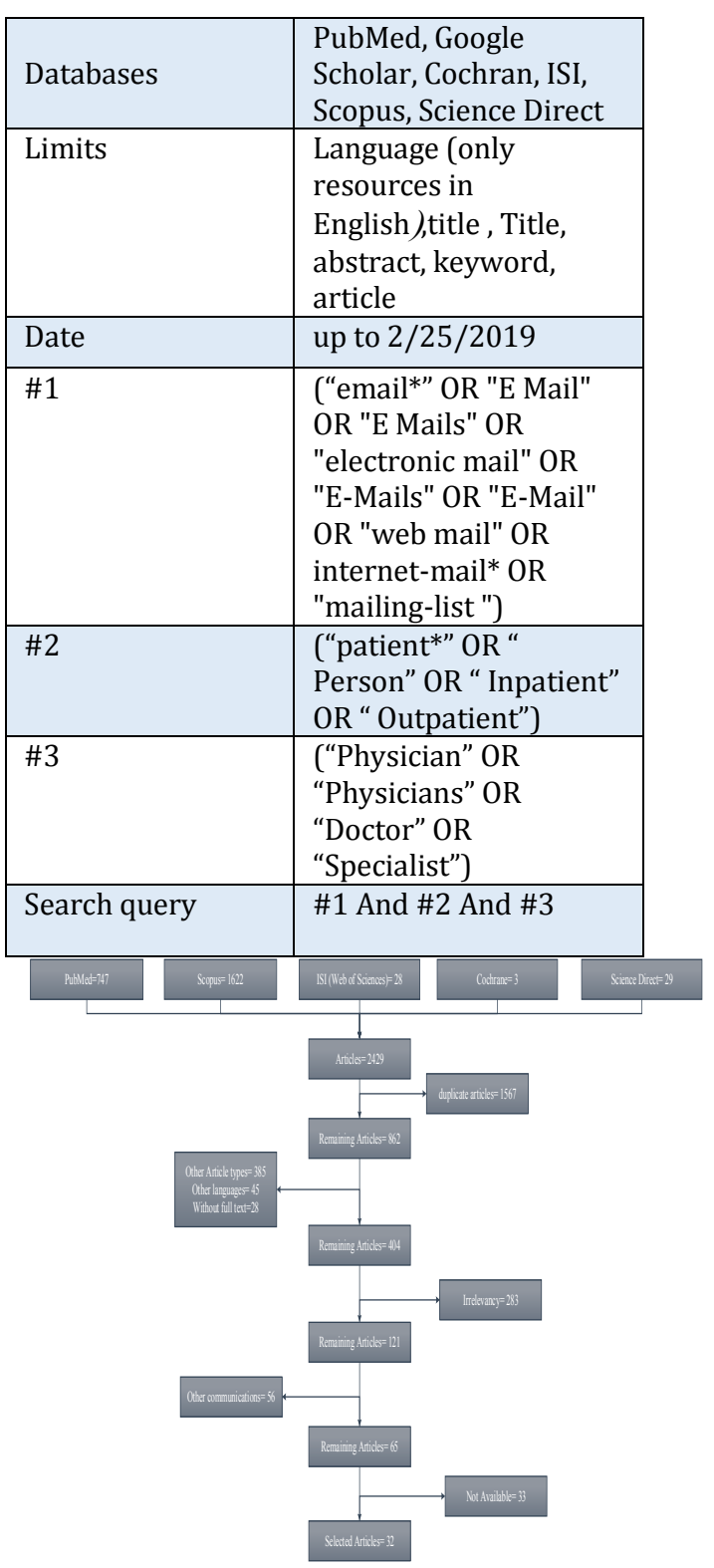

Fig 1: The PRISMA flowchart for the paper selection process

Using of email was for patient's communication with other healthcare providers except physician regardless of the study time limitation. Selection of articles was based on PRISMA statement in Fig 1 and finding 32 articles out of 2429 retrieved articles were included in the study. We include all related articles without time limitation, which published in English language. Also availability and relevancy of articles were considered.

All other types of articles including case reports, letters to editor and letters from editor, short communication, 
and conferential articles excluded from the study. All articles except in English language were excluded. The articles which were irrelevance to the study subject, excluded. All articles which using other communication methods, using email as a complementary communication way, using email for communication between patients, and communication between healthcare professionals were excluded.

In the manual search (Gray Literature) we fund two another articles, and totally 34 articles included in the study. By using a data gathering form the relevant information of selective articles were collected. Data were summarized and reported based on the research objectives using content analysis technique.

\section{RESULTS}

34 articles of total articles with included criteria were selected in which the largest numbers was in 2003 with 6 articles $(17.65 \%)$ and the most of them were done in United States with 26 studies (46.47\%). The most data gathering tool was questionnaire.

The results of this study showed that the average of email communication period between physicians and patients lasts three months to one year. Based on the findings it's also indicated that using email leads to improvement in healthcare quality in some cases $[\underline{15}$, $\underline{18}, \underline{20}]$.

The obtained results from included 34 studies showed in two following tables. Based on the results of this study, email was regarded as web-based and software-based communication.

Table 2 shows details of categorization of email communication between physician and patient that are put in 4 main dimensions.

Based on Table 2 Laboratory resources and obtaining health information in order to prevent diseases were among the most important emails subject.

Furthermore, other findings showed that in some cases the physicians-patients' satisfaction of email communications was suitable in Table 4 [요 $\underline{18}, \underline{32}]$.

Table 3 introduces threats and restrictions of email communication. Based on that the possibility of misdiagnosing pointed amongst the most important threatens and security limitation amongst the most important restrictions.

The other results of this study in Table 4 show the advantageous and disadvantageous of using email between physicians and patients.
Table 2: Categorization of email communication between physician and patient

\begin{tabular}{|c|c|c|}
\hline $\begin{array}{l}D_{0}^{2} \\
\sum_{\Sigma}\end{array}$ & Feature & Types \\
\hline 1 & $\begin{array}{l}\text { Response time } \\
\text { of email }\end{array}$ & $\begin{array}{l}\text { Same-day response time } \\
\text { of email }[\underline{8}, \underline{12}], \text { to } 72 \\
\text { hours after receiving email } \\
{[\underline{37}, \underline{38}]} \\
\text { Response time rate of } \\
\text { email by physician } 2-60 \\
\text { min }[\underline{8}, \underline{10}, \underline{12}, \underline{24}, \underline{28}]\end{array}$ \\
\hline 2 & Type of disease & $\begin{array}{l}\text { Diabetes, blood pressure } \\
{[\underline{5}, \underline{32}, \underline{36]} \text {, asthma [ } \underline{32},} \\
\underline{36}], \text { cardiovascular }[\underline{11} \\
\underline{20}, \underline{32}, \underline{36}], \text { Psoriasis }[\underline{20}], \\
\text { allergy, high cholesterol, } \\
\text { depression }[\underline{11}, \underline{36}]\end{array}$ \\
\hline 3 & $\begin{array}{l}\text { Type of } \\
\text { specialty }\end{array}$ & $\begin{array}{l}\text { General practitioner and } \\
\text { family physician }[\underline{23}, \underline{35}, \\
\underline{36}], \text { primary care } \\
\text { practitioner }[\underline{7}, \underline{12}, \underline{13}, \underline{16}, \\
\underline{25}, \underline{26}, \underline{28}, \underline{30}, \underline{36}, \underline{37}, \underline{39}, \\
\underline{40}], \text { surgeon }[\underline{12}, \underline{16}, \underline{3}, \\
\underline{36}], \text { internist }[\underline{16}, \underline{36}], \\
\text { gynecologist }[\underline{5} \underline{16} \underline{\underline{28}}], \\
\text { neurologist, emergency } \\
\text { specialist, psychiatrist } \\
{[\underline{28}], \text { pediatrician }[\underline{26}, \underline{35}-} \\
\underline{37}]\end{array}$ \\
\hline 4 & $\begin{array}{l}\text { Email subject in } \\
\text { relation } \\
\text { between } \\
\text { physician and } \\
\text { patient }\end{array}$ & 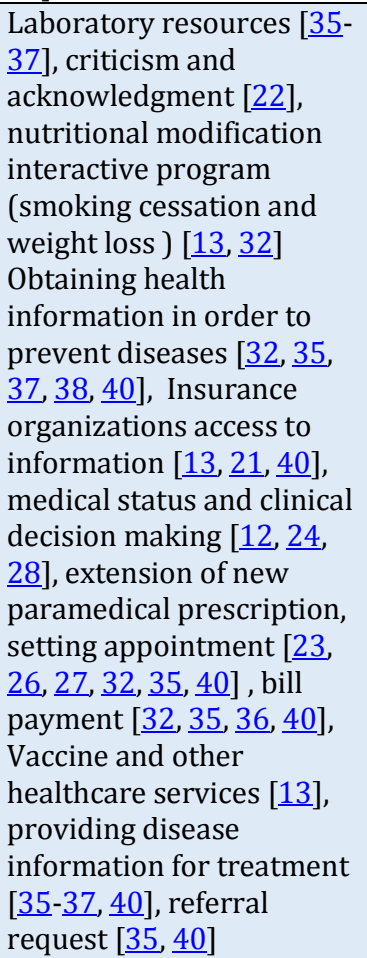 \\
\hline
\end{tabular}


Table 3: current threatens and limitation of email communication between physician and patient

\begin{tabular}{|l|l|l|}
\hline Row & Main theme & Subthemes \\
\hline 1 & Threatens & $\begin{array}{l}\text { Medical risks and the possibility of misdiagnosing }[\underline{4}, \underline{5}, \underline{17}, \underline{31}, \underline{37}], \text { using of email for making } \\
\text { trouble for physicians }[\mathbf{8}, \underline{15}, \underline{27}, \underline{35}, \underline{37}], \text { confidentiality of data }[\underline{7}, \underline{8}, \underline{12}, \underline{15}, \underline{17}, \underline{27}, \underline{31}] .\end{array}$ \\
\hline 2 & limitation & $\begin{array}{l}\text { Security limitations }[\underline{26}, \underline{32}, \underline{39}, \underline{40}] \text {, limitations on costs repayment }[\underline{26}, \underline{30}], \text { misunderstanding } \\
\text { of some information by patients [20], the possible misusing [26] }]\end{array}$ \\
\hline
\end{tabular}

Table4: the advantageous and disadvantageous of using email between physicians and patients

\begin{tabular}{|c|c|c|}
\hline Row & Advantageous & disadvantageous \\
\hline 1 & $\begin{array}{l}\text { Healthcare quality improvement and the ability to add } \\
\text { information to patients health record }[15, \underline{18}, \underline{20}]\end{array}$ & $\begin{array}{l}\text { Repayments by patients and increasing the costs }[\underline{20} \text {, } \\
\underline{31,35]}\end{array}$ \\
\hline 2 & Saving physician and patient time $[\underline{25}, \underline{28}, \underline{32}]$ & Required time to answer patients' email $[\underline{27}, \underline{28}, \underline{40}]$ \\
\hline 3 & $\begin{array}{l}\text { Increasing the patients' incorporation in medical } \\
\text { decisions making }[\underline{5}, \underline{6}, \underline{12}, \underline{18}, \underline{20}, \underline{32}]\end{array}$ & Increasing workload $[\underline{37}-\underline{40}]$ \\
\hline 4 & $\begin{array}{l}\text { More communication with patients despite reduction } \\
\text { in transferring virus }[\underline{13}, \underline{15}, \underline{20}, \underline{39}]\end{array}$ & Email sender authentication $[\underline{17} \underline{40}]$ \\
\hline 5 & $\begin{array}{l}\text { Solving patients problems and breaking the barriers of } \\
\text { communication between physicians and patients }[\underline{8} \text {, } \\
\underline{18}, \underline{32}]\end{array}$ & $\begin{array}{l}\text { Distrust of healthcare quality of clinical advices [ }[\underline{20} \\
\underline{31}]\end{array}$ \\
\hline 6 & It is convenient while visiting patients $[\underline{12}, \underline{18}, \underline{32}]$ & Lack of cognizance of creating email [ $\underline{35}]$ \\
\hline 7 & $\begin{array}{l}\text { Reduction of the number of visiting and telephone } \\
\text { contacts in clinic }[\underline{12}, \underline{13}, \underline{25}]\end{array}$ & $\begin{array}{l}\text { Disinterest in communicating with physician by } \\
\text { patient }[\underline{40}]\end{array}$ \\
\hline 8 & more sense of security and less threaten $[\underline{8}, \underline{21}]$ & Loss of information $[\underline{40}]$ \\
\hline 9 & $\begin{array}{l}\text { Updating patients' information and having a more } \\
\text { precise record in total }[\underline{32}, \underline{35}]\end{array}$ & Having negative impact on physicians' life [ $\underline{4}]$ \\
\hline 10 & More visiting fee for more services [32] & \\
\hline 11 & Reduction the medical errors [25] & \\
\hline
\end{tabular}

\section{DISCUSSION}

The results of this study showed that $24 \%$ of included studies emphasized the improvement in healthcare quality and creation of precise health record using email communication. Boukus et al. expressed that email is a tool to improve communication between physician and patient and also for patient's healthcare service. It suggested that email or other electronic tools could improve the communications, quality, patients' results, and increase patients' satisfaction as well as enthusiasm [23]. Leong et al. concluded that email is a wide kind of communication that is part of Electronic Health Record (EHR) that causes increasing healthcare services and improving patients' health results [12]. However, few studies pointed at inefficiency of using email for physician and patient communication [프] .

Using of email in communication between physician and patient have various consequences which mean that in some specialties exploiting it is effective, but the obtained results from some studies and particular specialties do not point at positive effect of email on control group. Sittig pointed that email is an important method to develop communication between physician and patient and since physicians are worried over the number of patients that causes them confused, it is suggested that the patients' requests could be done by using email; that results in saving time instead of telephone contact or visiting at clinic []. Even though the majority of studies pointed at the positive impact of using email in terms of physician and patient communication, but few studies pointed at its inefficiency, Therefore, it sounds it needs conducting more studies regarding the area of email communication between physician and patient.

The results of the current study emphasize involvement of patients in medical decision making with the help of email in communication between physician and patient. Menachemi et al. concluded that it is better to introduce a program to patients in order to provide guidelines to teach them the best performances [22] .

Other results of this study showed that it is possible to use email in communication between physician and patient as a complementary communication alongside traditional communication methods, that is not be considered as a stand-alone basis for communication and never be a replacement for traditional communications. Katez also found the same results [프].

The results showed that reimbursement on communicating with physicians is one of the issues of using email in communication between physician and patient. Peleg et al. suggest that asking patients to put 
down a deposit can schedule patients' subsequent interactions with clinics [14]. To manage the mass of emails, clinics' staffs are suggested to be used to manage emails, medical results explanation and online healthcare reimbursement mechanism [20].

The findings of this study showed that security is a limitation to email communication between physician and patient. Regarding the importance of security in physician and patient communication, it is pointed at using of email security feedback in many studies $[\underline{5}, \underline{13}, \underline{17}, \underline{24}, \underline{28}]$.

The amount of physicians' workload is a hindrance to create communication between physician and patient that in some studies, its increase contributed to the increasing number of emails to physicians by patients that results in refusal to create such communication by physicians, and in some other studies it is considered to be has positive effect or even ineffective. Leong et al. say that email increases the duration of response time to patients' emails, treatment, and their visiting, but does not increase physician workload [12]. However, Fridsma et al. express that it is possible to prevent high workload on physicians and also improve patients' healthcare by using electronic messages applicable methods []].

\section{CONCLUSION}

Using of email' capabilities has a significant role in improving the quality of health care services, therefore, with regard to the results of this study it is suggested it be used as a tool for communication between physicians and patients. Considering the email communication between physician and patient that is a major problem in reimbursement, therefore, a contract between insurer and physicians for reimbursement, making available both electronic insurance cards (for clinics that support email communication) and in print insurance card for other clinics should be taken into consideration. Because of the importance of the subject, it is suggested to conduct more studies in relation to email communication between physician and patient so that to identify precisely the type and the effect of it on physicians' performance and efficiency. Based on the result of this study, it is suggested that email be used for consulting, diseases treatment and diseases prevention. It also seems necessary to carry out some studies in order to determine physicians and patients' satisfaction, effectively, efficiency and profitability regarding email communication. Considering the patients' level of access to email and their ability to use it could be a proper solution to use email effectively in physician and patient communication.

\section{AUTHOR'S CONTRIBUTION}

All the authors approved the final version of the manuscript.

\section{CONFLICTS OF INTEREST}

The authors declare no conflicts of interest regarding the publication of this study.

\section{FINANCIAL DISCLOSURE}

No financial interests related to the material of this manuscript have been declared.

\section{REFERENCES}

1. Ortiz E, Clancy CM. Use of information technology to improve the quality of health care in the United States. Health Serv Res. 2003; 38(2): xi-xxii. PMID: 12785557 DOI: $10.1111 / 1475-6773.00127$ [PubMed]

2. Ziadlou D, Eslami A, Hassani HR. Telecommunication methods for implementation of telemedicine systems in crisis. Third International Conference on Broadband Communications, Information Technology \& Biomedical Applications. IEEE; 2008.

3. Dash J, Haller DM, Sommer J, Junod Perron N. Use of email, cell phone and text message between patients and primary-care physicians: Cross-sectional study in a French-speaking part of Switzerland. Health Serv Res. 2016; 16(1): 549-56. PMID: 27716256 DOI: 10.1186/s12913-016-1776-9 [PubMed]

4. Singh H, Fox SA, Petersen NJ, Shethia A, Street RL. Older patients' enthusiasm to use electronic mail to communicate with their physicians: Cross-sectional survey. J Med Internet Res. 2009; 11(2): e18. PMID: 19632972 DOI: 10.2196/jmir.1143 [PubMed]

5. Gerstle RS. E-mail communication between pediatricians and their patients. Pediatrics. 2004; 114(1): 317-21. PMID: 15231952 [PubMed]

6. Samadbeik M, Ahmadi M, Mohammadi A, Mohseni Saravi B. Health information on Internet: Quality, importance, and popularity of persian health websites. Iran Red Crescent Med J. 2014; 16(4): 112. PMID: 24910795 DOI: 10.5812 /ircmj.12866 [PubMed]

7. Fridsma DB, Ford P, Altman R. A survey of patient access to electronic mail: Attitudes, barriers, and opportunities. Proc Annu Symp Comput Appl Med Care. 1994; 1: 15-9. PMID: 7949909 [PubMed]

8. Sittig DF. Results of a content analysis of electronic messages (email) sent between patients and their physicians. BMC Med Inform Decis Mak. 2003; 3(1): 11-6. PMID: 14519206 DOI: 10.1186/14726947-3-11 [PubMed]

9. Kashgary A, Alsolaimani R, Mosli M, Faraj S. The role of mobile devices in doctor-patient communication: A systematic review and meta-analysis. J Telemed Telecare. 2017; 23(8): 693-700. PMID: 27632990 DOI: $10.1177 / 1357633 X 16661604$ [PubMed]

10. Patel PB, Vinson DR. Physician e-mail and telephone contact after emergency department visit improves patient satisfaction: A crossover trial. Ann Emerg Med. 
2013; 61(6): 631-7. PMID: 23465304 DOI: 10.1016/j.annemergmed.2012.12.005 [ㅁuMed]

11. Lee JL, Choudhry NK, Wu AW, Matlin OS, Brennan TA, Shrank WH. Patient use of email, facebook, and physician websites to communicate with physicians: A national online survey of retail pharmacy users. J Gen Intern Med. 2016; 31(1): 45-51. PMID: 26105675 DOI: $10.1007 / \mathrm{s} 11606-015-3374-7$ [PubMed]

12. Leong SL, Gingrich D, Lewis PR, Mauger DT, George JH. Enhancing doctor-patient communication using email: A pilot study. J Am Board Fam Med. 2005; 18(3): 180-8. PMID: 15879565 [PubMed]

13. Baer D. Patient-physician e-mail communication: The Kaiser Permanente experience. J Oncol Pract. 2011; 7(4): 230-3. $\quad$ PMID: 22043186 DOI: 10.1200/JOP.2011.000323 [PubMed]

14. Peleg R, Avdalimov A, Freud T. Providing cell phone numbers and email addresses to patients: The physician's perspective. BMC Res Notes. 2011 23;4(1): 76-84. PMID: 21426591 DOI: 10.1186/17560500-4-76 [PubMed]

15. Dash J, Haller DM, Sommer J, Perron NJ. Use of email, cell phone and text message between patients and primary-care physicians: cross-sectional study in a French-speaking part of Switzerland. Health Serv Res. 2016; 16(1): 549-56. PMID: 27716256 DOI: 10.1186/s12913-016-1776-9 [PubMed]

16. Eysenbach G. Towards ethical guidelines for dealing with unsolicited patient emails and giving teleadvice in the absence of a pre-existing patient-physician relationship: Systematic review and expert survey. J Med Internet Res. 2000; 2(1): e1. PMID: 11720920 DOI: 10.2196/jmir.2.1.e1 [PubMed]

17. Bovi AM. Ethical guidelines for use of electronic mail between patients and physicians. Am J Bioeth. 2003; 3(3): 43-7. PMID: 14735881 DOI: 10.1162/152651603322874771 [PubMed]

18. Garrido T, Meng D, Wang JJ, Palen TE, Kanter MH. Secure e-mailing between physicians and patients: Transformational change in ambulatory care. J Ambul Care Manage. 2014; 37(3): 211-8. PMID: 24887522 DOI: $10.1097 / J A C .0000000000000043$ [PubMed]

19. Brooks RG, Menachemi N. Physicians' use of email with patients: factors influencing electronic communication and adherence to best practices. J Med Internet Res. 2006; 8(1): e2. PMID: 16585026 DOI: 10.2196/jmir.8.1.e2 [PubMed]

20. Patt MR, Houston TK, Jenckes MW, Sands DZ, Ford DE. Doctors who are using e-mail with their patients: A qualitative exploration. J Med Internet Res. 2003; 5(2): e9. PMID: 12857665 DOI: 10.2196/jmir.5.2.e9 [PubMed]

21. Lang 2nd KT, Kiel JM. An analysis of the utilization of e-mail by physicians and patients: Defining benefits, addressing concerns and forecasting implications on the doctor-patient relationship. J Healthc Inf Manag 2008; 22(2): 27-32. PMID: 19266992 [PubMed]
22. Menachemi N, Prickett CT, Brooks RG. The use of physician-patient email: A follow-up examination of adoption and best-practice adherence 2005-2008. J Med Internet Res. 2011; 13(1): e23. PMID: 21447468 DOI: 10.2196/jmir.1578 [PubMed]

23. Boukus ER, Grossman JM, O'Malley AS. Physicians slow to e-mail routinely with patients. Issue Brief Cent Stud Health Syst Change. 2010; 134: 1-5. PMID 20939158 [PubMed]

24. Zhou YY, Kanter MH, Wang JJ, Garrido T. Improved quality at Kaiser Permanente through e-mail between physicians and patients. Health Aff. 2010; 29(7): 1370-5. PMID: 20606190 DOI: 10.1377/hlthaff.2010.0048 [PubMed]

25. Hobbs J, Wald J, Jagannath YS, Kittler A, Pizziferri L, Volk LA, et al. Opportunities to enhance patient and physician e-mail contact. Int J Med Inf. 2003; 70(1): 19. PMID: 12706177 [PubMed]

26. Siva C, Lawlor K, Smarr K, Ge B, Fleming D. E-mail communication with patients: A survey of the American College of Physicians, Missouri Chapter. Mo Med. 2011; 108(2): 136-40. PMID 21568238 [PubMed]

27. Sands DZ. Help for physicians contemplating use of email with patients, J Am Med Inform Assoc. 2004; 11(4): 268-69. PMID: 15252925 doi: $10.1197 /$ jamia.M1576 [PubMed]

28. Houston TK, Sands DZ, Nash BR, Ford DE. Experiences of physicians who frequently use e-mail with patients. Health Communication. 2003; 15(4): 515-25.

29. Atherton H, Sawmynaden P, Sheikh A, Majeed A, Car J. Email for clinical communication between patients/caregivers and healthcare professionals. Cochrane Database of Systematic Reviews. 2012; 8(3): 1-4. PMID: 23152249 DOI: 10.1002/14651858.CD007978.pub2 [PubMed]

30. Liebhaber AB, Grossman JM. Physicians slow to adopt patient e-mail. Data Bull (Cent Stud Health Syst Change). 2006; 32: 1-2. PMID: 16995287 [PubMed]

31. Stensgaard T, Arnfjord M, Karlsen M, Mulvad G. E-mail contact between patients and doctors in primary health care. Int J Circumpolar Health. 2004; 63(sup2): 133-4.

32. Delbanco T, Walker J, Darer JD, Elmore JG, Feldman HJ, Leveille SG, et al. Open notes: Doctors and patients signing on. Ann Intern Med. 2010; 153(2): 121-5.

33. Baur C. Limiting factors on the transformative powers of e-mail in patient-physician relationships: A critical analysis. Health Communication. 2000; 12(3): 239-59. PMID: 10938915 DOI: 10.1207/S15327027HC1203_02 [PubMed]

34. Adams S, Bal R, De Jong J. Full of promise, failed in practice: A discussion of barriers encountered during an attempt to integrate physician-patient e-mail communication in the care process at a Dutch eye hospital. Int J Technol Manag. 2005; 7(3-4): 252-65.

35. Katz SJ, Moyer CA, Cox DT, Stern DT. Effect of a triagebased e-mail system on clinic resource use and patient and physician satisfaction in primary care: A 
randomized control trial. J Gen Intern Med. 2003; 18(9): 736-44. PMID: 12950483 doi: 10.1046/j.15251497.2003.20756.x [PubMed]

36. Sciamanna CN, Rogers ML, Shenassa ED, Houston TK. Patient access to US physicians who conduct internet or e-mail consults. J Gen Intern Med. 2007; 22(3): 37881. PMID: 17356972 DOI: $10.1007 / s 11606-006-$ 0076-1 [PubMed]

37. Rosen P, Kwoh CK. Patient-physician e-mail: An opportunity to transform pediatric health care delivery. Pediatrics. 2007; 120(4): 701-6. PMID: 17908755 DOI: 10.1542/peds.2007-1094 [PubMed]

38. Roter DL, Larson S, Sands DZ, Ford DE, Houston T. Can e-mail messages between patients and physicians be patient-centered? Health Commun. 2008; 23(1): 80-6. PMID: 18443995 DOI: 10.1080/10410230701807295 [PubMed]

39. Luo J, Logan C, Long TP, Bercovitch L. Cyberdermatoethics I: Ethical, legal, technologic, and clinical aspects of patient-physician e-mail. Clin Dermatol. 2009; 27(4): 359-66. PMID: 19539163 DOI: 10.1016/j.clindermatol.2009.02.008 [PubMed]

40. Broom A. Virtually healthy: The impact of internet use on disease experience and the doctor-patient relationship. Qual Health Res. 2005; 15(3): 325-45. PMID: 15761103 DOI: 10.1177/1049732304272916 [PubMed] 